\title{
Integration of Artificial Intelligence into Biogas Plant Operation
}

\author{
Samet Cinar, Senem Onen Cinar 1 , Nils Wieczorek, Ihsanullah Sohoo $\mathbb{1}$ and Kerstin Kuchta *
}

Sustainable Resource and Waste Management, Hamburg University of Technology, Blohmstr. 15, 21079 Hamburg, Germany; samet.cinar@tuhh.de (S.C.); senem.oenen@tuhh.de (S.O.C.); nils.wieczorek@tuhh.de (N.W.); sohoo.ihsanullah@tuhh.de (I.S.)

* Correspondence: kuchta@tuhh.de; Tel.: +49-(0)-40-428-78-2375

Citation: Cinar, S.; Cinar, S.O.;

Wieczorek, N.; Sohoo, I.; Kuchta, K. Integration of Artificial Intelligence into Biogas Plant Operation. Processes 2021, 9, 85. https://doi.org/10.3390/ pr9010085

Received: 30 October 2020 Accepted: 29 December 2020 Published: 2 January 2021

Publisher's Note: MDPI stays neutral with regard to jurisdictional clai$\mathrm{ms}$ in published maps and institutional affiliations.

Copyright: (C) 2021 by the authors. Licensee MDPI, Basel, Switzerland. This article is an open access article distributed under the terms and conditions of the Creative Commons Attribution (CC BY) license (https:// creativecommons.org/licenses/by/ $4.0 /)$.

\begin{abstract}
In the biogas plants, organic material is converted to biogas under anaerobic conditions through physical and biochemical processes. From supply of the raw material to the arrival of the products to customers, there are serial processes which should be sufficiently monitored for optimizing the efficiency of the whole process. In particular, the anaerobic digestion process, which consists of sequential complex biological reactions, requires improved monitoring to prevent inhibition. Conventional implemented methods at the biogas plants are not adequate for monitoring the operational parameters and finding the correlation between them. As Artificial Intelligence has been integrated in different areas of life, the integration of it into the biogas production process will be inevitable for the future of the biogas plant operation. This review paper first examines the need for monitoring at the biogas plants with giving details about the process and process monitoring as well. In the following sections, the current situation of implementations of Artificial Intelligence in the biogas plant operation and in the similar industries will be represented. Moreover, considering that all the information gathered from literature and operational needs, an implementation model will be presented.
\end{abstract}

Keywords: process optimization; artificial intelligence; biogas plant; process monitoring; anaerobic digestion; predictive monitoring; automation

\section{Introduction}

The primary energy consumption of the world increased by 51,000 TWh between 2000 and 2019, from 122,000 TWh to 173,000 TWh. During this time, the highest increases were observed at the electricity supplied from oil, coal and natural gas [1]. Germany plans to have clean energy sources by 2038 with the strategy of replacing nuclear energy, coal and oil, which have the biggest contribution for energy production today. According to 'Climate Action Plan 2050 of Germany', 40\% of greenhouse gas by 2020, 55\% by 2030, $80-95 \%$ by 2050 should be reduced with base year of 1990 [2]. Renewable energy gained importance by means of innovation and incentives between the years 2006-2012, after 2012 the applications for patents decreased [3]. In addition, the number of publications were analysed using "renewable energy" keyword on the Scopus Website, which presented a decrease in the number of publications after 2018 [4].

In 2014 , biogas shared $7.6 \%$ of total renewable energy production in Europe, which were used for electricity, heat and biofuel production [5]. The average growth rate of electricity produced from biogas dropped between the years 2016-2017 compared to growth between 2014 and 2016 [6]. According to the European Commission, the share of renewable energy in the total energy consumption should be $32 \%$ by 2030 [7].

Anaerobic digestion (AD) is a biochemical process conducted by various kinds of microorganisms to produce biogas from complex organic materials in anaerobic conditions. Several substrates are implemented in the process as substrate, such as animal excrements, agricultural residues, organic wastes from industries, organic fraction of municipal solid 
waste, food waste, sewage sludge and dedicated energy crops [8]. To supply a suitable environment for the microorganisms, adequate process monitoring is required [9].

Artificial Intelligence (AI), which briefly is the usage of data science to be able to create predictive and self-deciding systems and environments and provides efficient alternative for conventional methods, has made great progress in various areas in recent years [10-12]. As it is commonly used in other industries, artificial intelligence tools can be used for designing and optimizing complex AD process [13,14]. In addition, future biogas plants in Germany will be operated more flexibly than today regarding maintenance and production of biogas, which will require improved monitoring [15-17]. Integration of artificial intelligence into the monitoring can supply efficient predictive maintenance that brings flexibility to the process [18]. Demand-driven electricity feed into the electricity grid can be realized with flexible biogas plants instead of storing the produced energy $[19,20]$.

This paper inspects the current situation of the implementation of artificial intelligence in biogas plant technologies with determining general process needs and possible areas for the integration of the future oriented technologies for optimizing the process.

\section{Anaerobic Digestion Process}

\subsection{Overview of the Process}

Within the AD process, biomass is converted to biogas through complex biochemical serial reactions. The produced biogas is processed in the Combined Heat and Power (CHP) Plant unit to produce heat and electricity [21]. Generally, a biogas plant includes a storage area for biomass, pre-treatment, digester where the biochemical process is conducted, biogas processing units and digestate processing units (see Figure 1) [8,21-23].

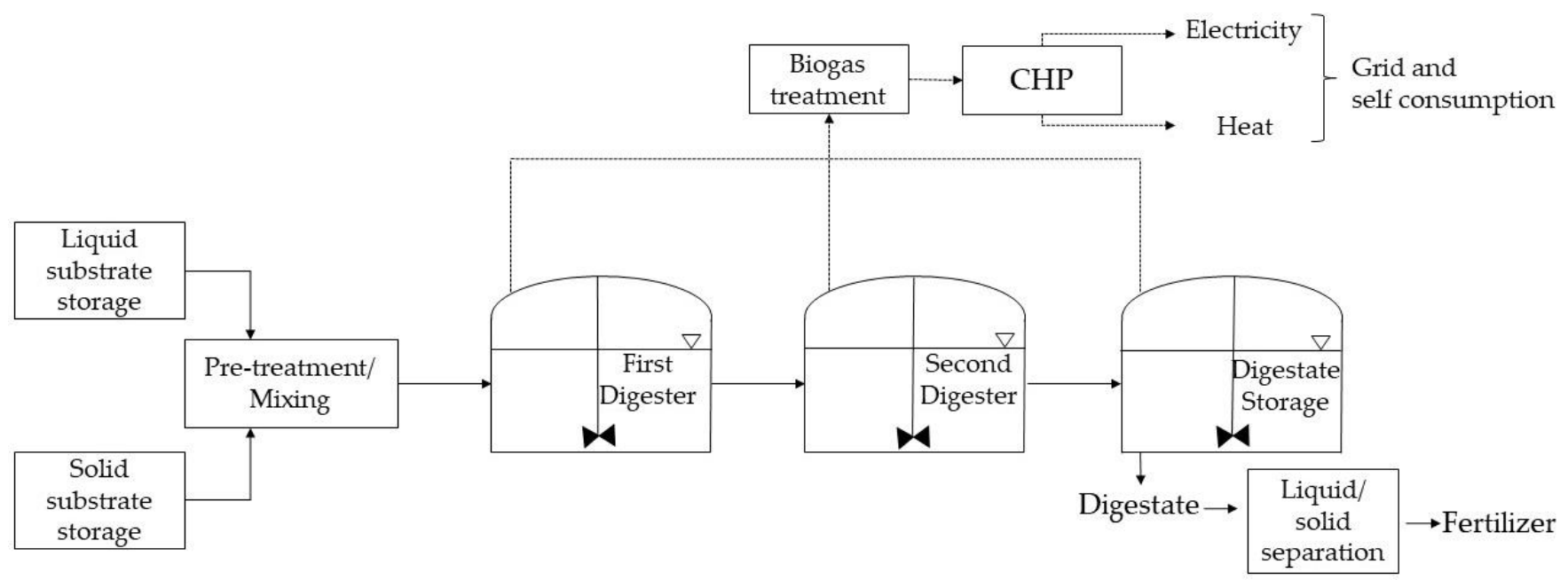

Figure 1. General overview of the anaerobic digestion (AD) process.

Four different criteria are determined to define process features in the anaerobic digestion, such as, Total Solids (TS) content of the digestate (dry digestion or wet digestion), type of feeding (continuous, semi-continuous or discontinuous), number of phases (single-stage or two-stage) and process temperature (psychrophilic, mesophilic and thermophilic) [24].

Energy crops, agricultural residues, bio and municipal solid waste, industrial waste and sewage are the mainly used substrates in Europe's biogas plants [25]. Several pretreatment technologies can be implemented to (1) obtain a faster AD process, (2) increase the biogas yield, (3) utilize available substrates, and prevent problems at the process. Generally, pre-treatment methods can be classified as represented in Table 1 [24]. 
Table 1. General classification of pretreatment methods [22].

\begin{tabular}{ccccc}
\hline Principle & Physical & Chemical & Biological & Combined Processes \\
\hline \multirow{3}{*}{ Technique } & Mechanical & Alkali & Microbiological & Steam explosion \\
& Thermal & Acid & Enzymatic & Extrusion \\
& Ultrasound & Oxidative & Thermochemical \\
\hline
\end{tabular}

\subsection{Stages of the AD Process}

The AD process consists of four sequential stages; hydrolysis, acidogenesis, acetogenesis and methanogenesis as presented in Figure 2. The microorganisms taking part at each stage varies based on physiology, nutrition needs, growth kinetics and sensitivity to the environmental conditions. Carbohydrates, proteins and lipids are converted to $\mathrm{CO}_{2}$ and $\mathrm{CH}_{4}$ within four stages of the $\mathrm{AD}$ process, where facultative anaerobic bacteria, acidogenic bacteria, acetogenic bacteria and methanogenic bacteria are taking part [26,27].

Hydrolysis is the first stage of the AD process, where the conversion of insoluble materials and high molecular mass compounds into the soluble form through enzymatic reactions occurs. Specific enzymes take part in the conversion process of different kind of substrates, such as proteinase for proteins, cellulase for cellulose, lipase for fats etc. [28]. The composition of the substrate plays an important role at the kinetics of the reaction [27]. Although each enzyme has its own optimum temperature range, most of the enzymes are stable up to $55^{\circ} \mathrm{C}[29,30]$. The monomers produced in the hydrolysis stage are converted into organic acids and alcohols in the acidogenesis stage [27]. In that stage, decrease at the $\mathrm{pH}$ value and production of by products (ammonia and hydrogen sulfide) are observed [31] In the third stage, products like Volatile Fatty Acids (VFA) and alcohol are oxidized into acetate, hydrogen and carbon dioxide to be used by methanogens for the generation of the final product, methane $[26,27,32]$. In the last phase, hydrogen and carbon dioxide are converted into methane by methanogenic microorganisms. That phase is most critical phase, due to the high sensitivity of the methanogenic bacteria [27,31].

\subsection{Operational Parameters of the Biogas Plant}

The efficiency of the AD process is dependent on various parameters, such as feedstock composition (FC), reactor design (RD), inhibitors and toxins (I and T), TS and Volatile Solids (VS) contents, Organic Loading Rate (OLR), Hydraulic Retention Time (HRT), Volatile Fatty Acids (VFA), $\mathrm{pH}$ and temperature (T) (see Figure 2).

Feedstock composition: Agricultural residues, energy crops, sewage sludge, biowaste and municipal solid waste and industrial food and beverage waste are mainly used substrates in the biogas plants in Europe [25,33]. Particle size, TS content and C/N ratio are significant parameters and has effect on process efficiency and design of the process $[21,34]$. The required ratio of macronutrients for survival of the microorganisms is C:N:P:S = 600:15:5:1 [35].

Reactor design: A biogas plant consists of storage and treatments, digestion unit, gas storage, pipework and armatures and gas transformation unit. The amount and composition of the substrate has direct effect on the design of the components in the process [36].

Inhibitors/toxins: Ammonia, sulfide, light metal ions ( $\mathrm{Na}, \mathrm{K}, \mathrm{Mg}$, $\mathrm{Ca}$ and $\mathrm{Al})$, heavy metals ( $\mathrm{Cr}, \mathrm{Fe}, \mathrm{Co}, \mathrm{Cu}, \mathrm{Zn}, \mathrm{Cd}$ and $\mathrm{Ni}$ ), organic compounds lead to destruction of the process at specific concentrations [37]. Accumulation of the mentioned inhibitors or toxins can cause a decrease in the biomethane production and eventually failure of the process [37]. Hydrolytic bacteria taking part in the hydrolysis stage can be inhibited by excess amounts of VFAs, LCFAs, partial pressure of hydrogen and humic acids [38-40]. In addition, acetogenesis and methanogenesis stages are mainly inhbited by the accumulation of VFAs, ammonia and LCFAs [41]. Total ammonia concentration (TAN) higher than $7 \mathrm{~g} \mathrm{NL}^{-1}$ may cause the complete inhibition of the process [42]. A study conducted by Dasa et al. (2016) 
showed that palmitic and oleic acid with the concentrations of $3.0 \mathrm{~g} \mathrm{~L}^{-1}$ and $4.5 \mathrm{~g} \mathrm{~L}^{-1}$ caused inhibition $(>50 \%)$ in the thermophilic anaerobic digestion process [43]. Another study conducted by Palasti et al. (2009) reported that LCFAs concentrations excessing $1.0 \mathrm{~g} \mathrm{~L}^{-1}$ may cause inhibition of thermophilic anaerobic digestion process [44]. Nevertheless, the inhibition caused by LCFAs is not irreversible and can be recovered $[44,45]$. Ammonia inhibition in the anaerobic digestion process can be caused by ammonium ion $\left(\mathrm{NH}_{4}{ }^{+}\right)$and free ammonia $\left(\mathrm{NH}_{3}\right)$ [46]. According to conducted studies, TAN concentration should be kept between 500 and $6000 \mathrm{mg} \mathrm{NH}_{4}-\mathrm{N} \mathrm{L}^{-1}$ to supply optimum methane production as well as prevent the possible ammonia inhibition [47-49]. Another inhibition reason in the anaerobic digestion process is high concentrations of un-ionized $\mathrm{H}_{2} \mathrm{~S}$, that can inhibit lactose and acetate utilization in the process [50]. In addition to the mentioned organic compounds, light metals and heavy metals can have an inhibitory effect on the process with excess amounts. On the other hand, light and heavy metals are required for the metabolism of microorganims and for the enzymatic reactions [51,52]. A study conducted by Kumar et al. (2006) showed that there was improvement in biogas production after the addition of $2.5 \mathrm{mg} \mathrm{L}^{-1}$ heavy metals [53].

Total Solids (TS) and Volatile Solids (VS): TS content of the substrate determines the technologies implemented in the process, which are wet digestion and dry digestion [21]. Generally, in the wet digestion the feedstock contains $10-15 \%$ TS and it increases to $24-40 \%$ TS in the dry digestion [54]. VS is one of the most important parameters of the substrate, which is used for defining the specific biogas production capacity [21]. Similar biogas yields can be obtained from dry and wet digestion processes with suitable amount of substrate feeding [55].

Organic loading rate (OLR): OLR indicates the amount of volatile solids fed into the digester per unit working volume per unit time [21]. Increasing the OLR leads to an increase in the process efficiency [56]. OLR can be adjusted to recover inhibition caused by high ammonia concentrations [57,58].

Hydraulic retention time (HRT): HRT defines the duration time of the substrate in the system, which is calculated as dividing the reactor volume by daily substrate feeding volume [59]. Longer HRT enables enough time for effective degradation. On the other hand, with having short HRT, small working volumes are suitable to perform the process [32].

Volatile fatty acids (VFAs): VFAs are converted into acetate in AD process. Especially, they are significant indicators to determine the efficiency of the acetogenesis stage of $\mathrm{AD}[60,61]$. VFAs concentration higher than $2 \mathrm{~g} \mathrm{~L}^{-1}$ leads to the inhibition in the hydrolysis of cellulose [62,63].

$\mathrm{pH}$ : Different microorganisms taking part in the process requires different $\mathrm{pH}$ values for their optimum performance. $\mathrm{pH}$ of 5.2 to 6.3 for the hydrolyzing and acid forming bacteria and 6.5-8.0 for acetogenic and methanogenic archaea are needed for optimum biogas production [24]. Generally, ammonia inhibition leads to the accumulation of VFAs, which can be detected via high $\mathrm{pH}$ values [64].

Temperature (T): Anerobic digestion process is classified under three categories dependent on the operation temperature: Psychrophilic $\left(<25{ }^{\circ} \mathrm{C}\right)$, mesophilic $\left(37-42{ }^{\circ} \mathrm{C}\right)$ and thermophilic $\left(50-60^{\circ} \mathrm{C}\right)$. Temperature has a direct effect on microbial dynamics and efficiency of the process [65-67]. In addition, the activity of the enzymes is affected by temperature. Most of the enzymes are stable in the mesophilic temperature range [68]. On the other hand, an increase in the temperature leads to an increase in the ammonia concentration. Therefore, thermophilic process is more sensitive to ammonia inhibition than mesophilic process [21,69]. 


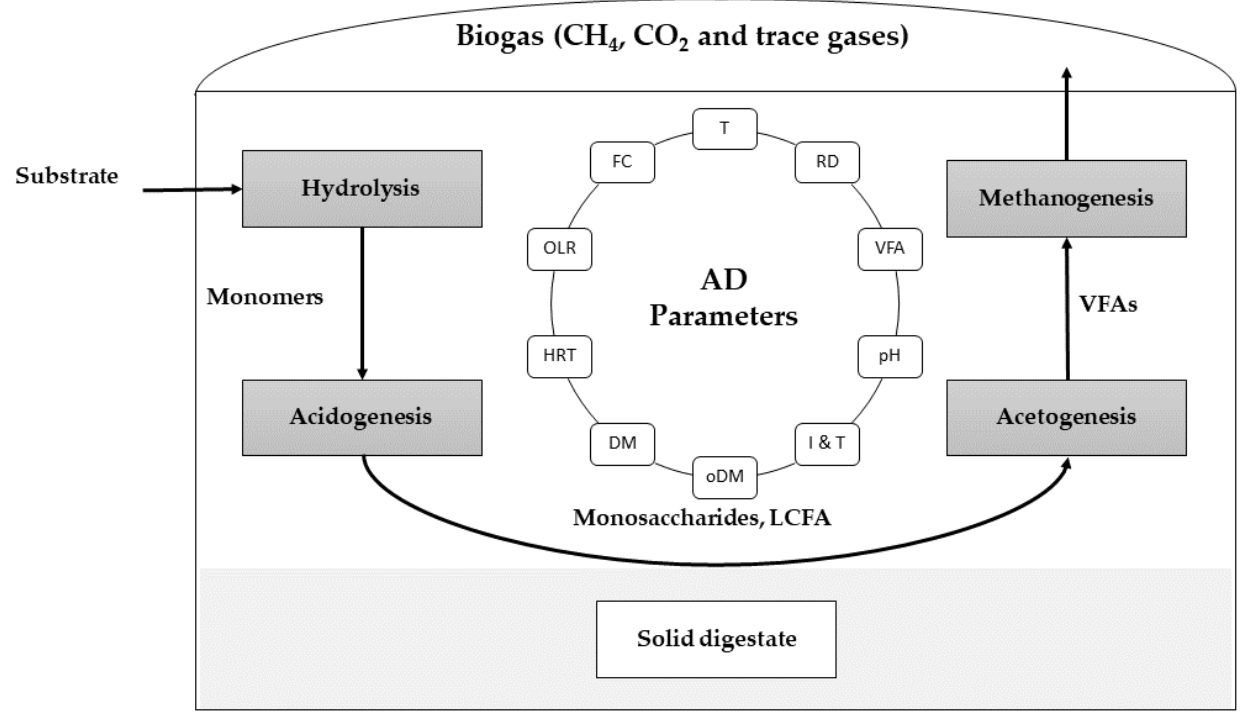

Figure 2. Operational parameters of the AD process (LCFA: long chain fatty acids) $[9,70,71]$.

\section{Process Monitoring and Control}

Process monitoring supplies overall ideas about the process, early detection of possible instabilities and enabling the successful start-up or re-start of the process [72,73].

\subsection{Overview of the Biogas Plant Monitoring and Control}

As was mentioned in a previous chapter, the AD process consists of serial stages, hydrolysis, acidogenesis, acetogenesis and methanogenesis. The stages of the process coexist, thus problems happening in a stage can affect the balance of the whole process. The time limiting step depends on the features of the substrate fed into the reactor $[74,75]$. Hydrolysis is accepted as a time limiting step for the complex organic substances, which cannot be easily hydrolyzed and leads to the accumulation of VFAs. On the other hand, the methanogenesis stage, that most important stage of the $\mathrm{AD}$ process, is the limiting step for easily degradable substrates [76-78].

One of the most focused topics in $\mathrm{AD}$ is online monitoring and control. The increase in the number of large-scale biogas plants also increases the demand for suitable monitoring and control of these systems [79]. Monitoring and control systems are applied differently depending on the applications. With online monitoring and control, process optimization is possible through maximizing the utilization of process capacity and minimizing the lost from process failure [80].

In order to be able to provide a sufficient level of energy with a sufficient stability and flexibility, system monitoring and control is required. In many cases, a strongly inhibited microorganism population or a total crash of the whole plant can have severe financial consequences for the biogas plant operators [81]. With process monitoring it is possible to get an overall picture of the biogas process, identify upcoming instabilities in anaerobic digesters before a crash happens, accompany a successful start-up or re-start of a plant $[71,74]$.

Feeding frequency directly affects process performance and microbial communities. A comparative study was conducted by Svensson et al. (2018), which showed that daily feeding causes greater fluctuations in acetate concentration and $\mathrm{pH}$ compared to the ten times a day feeding [82]. Moreover, changing the feedstock composition causes variations in the microbiology of the process and their performances [83]. For that reason, the change of substrate mixtures should be performed carefully, which enables adaptation of the process to new conditions [72].

Operation temperature of the digester affects the entire process by means of degradation rate, biogas yield and process stability [84]. Different kinds of microorganisms taking 
part in the biogas production process have their specific optimum growing temperatures, for example most of the methanogenic species have their optimum at mesophilic temperatures [85]. Generally, more than $\pm 3^{\circ} \mathrm{C}$ per day under mesophilic conditions and more than $\pm 1{ }^{\circ} \mathrm{C}$ under thermophilic conditions are to avoid within the AD process $[32,69,86-88]$.

To supply intensive contact between the microorganisms and the substrate, sufficient contact time is required, which can be supplied by suitable mixing strategy [84]. In addition, the creation of layers (floating layers and sedimentation) is prevented through adequate mixing $[21,61]$.

There are various problems that can be faced within the operation of biogas plants, which can be classified as follows:

- Structural components

- Piping system

- Biogas utilization equipment

- Digestate disposal system

- AD process and biogas production

- Knowledge related problems

- Further non-technical problems e.g., lack of finance and political restrictions [81,89].

Moreover, with the increase in the number of biogas plants, the number of accidents happening at the biogas plants is increasing quite fast because of the safety problems. The observed accidents are mostly fire, leakage, poisoning, environmental and deflagration/ explosion [90]. To prevent the possible problems mentioned above, performing a sustainable process, enhancing the process efficiency and preventing emissions, process monitoring and control are required among all biogas plants [36,91]. The complexity of the biogas production process is challenging, but future oriented biogas plants requires a flexible, stable and low cost online process control [36]. The importance of efficient monitoring and control in $\mathrm{AD}$ processes is beyond any doubt, due to being able to have a stable process and optimize the production of biogas. A laboratory-based control strategy of biogas plants should be converted to a process analytical strategy that relies on representative sampling, advanced sensor technology and multivariate data analysis [36].

\subsection{Currently Available Monitoring and Control Technologies}

Lack of monitoring and control in the biogas plants can lead to process failure. Both instruments used in the plant and the process parameters should be controlled within the process [92]. Control of the feed material, biogas quality, temperature, pressure, pumps, mixers and digester covers is required and implemented for the continuity of the process [92-94]. In addition, visual controls can supply fast and cost efficient detection of the problems, which is mainly implemented via a single tag on a pipe or a mounted glass [92]. On the other hand, there are various automatic control strategies for the biogas plants dependant on the expected complexity.

- On-off is a simple control strategy and suitable for valve and pump control. Nevertheless, it cannot supply fine control and it does not have direct effect process stability.

- PI (Proportional Integral)/PID (Proportional Integral Derivative) is a simple, robust and fine control strategy that does not require a model. The demerits of this strategy are its applicability with only linear systems and the strategy can be implemented for single input/ output systems.

- Adaptive control can be used for controlling non-linear/dynamic systems, that provide parameter estimation and anticipation of future disturbance. However, detailed information and complex mathematical calculations are required for the model, which can include uncertainties.

- Fuzzy logic can be implemented in multiple input/output and nonlinear systems, but highly relies on the expertise of the operator.

- Artificial neural network does not require a model or expertise. Training time and large information are required [95]. 
In general, monitoring strategies of $\mathrm{AD}$ process can be classified under three categories: Minimum, standard and advanced monitoring as in Figure 3 [71]. Process monitoring is required for determining the character of the process or for early indication of problems [96]. Monitoring of different operational parameters at the biogas plants can be performed as online, which defines real-time measurements of the parameters at the biogas plant or off-line monitoring through laboratory analysis. In addition to these two technologies, at-line monitoring can be implemented to analyze samples with sensors in the pipeline, which represents the real situation in the reactor as well [97].

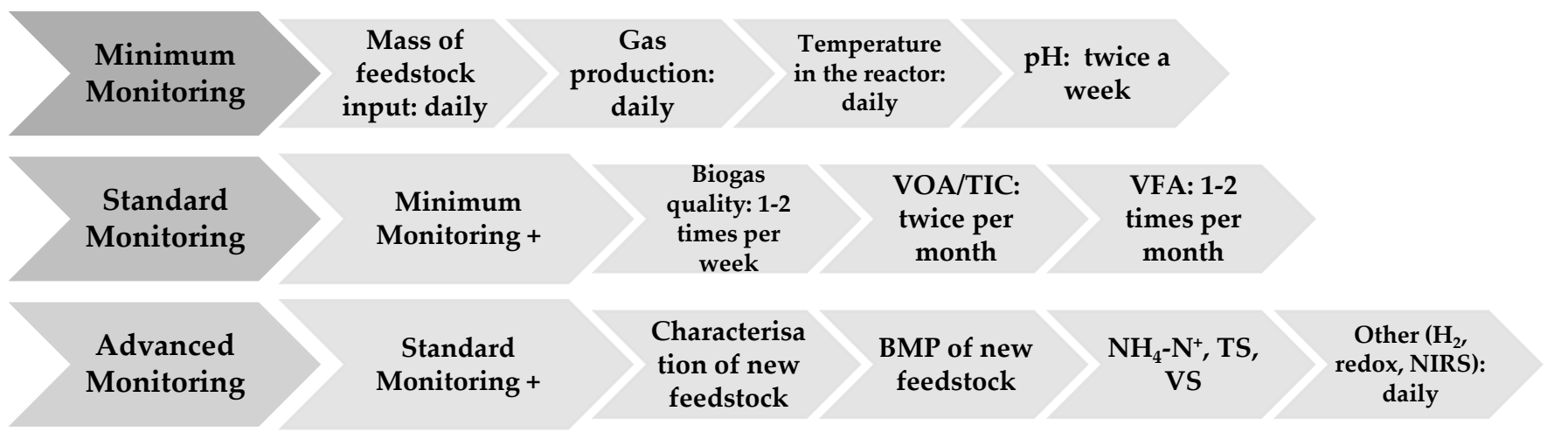

Figure 3. Classification of monitoring strategies [71]. VOA/TIC: Volatile Organic Acids/Total Inorganic Carbon, BMP: Biomethane Potential.

\subsection{Future Prospective in Biogas Plant Monitoring}

Despite common implementation of the biogas production technologies around the world, there is still a need to improve monitoring strategies for improving the efficiency $[45,98,99]$. Online monitoring is inevitable for future oriented biogas plants, but the parameters should be determined carefully. In the studies performed, it was found that $\mathrm{pH}$ is not an early instability detection parameter, relying on organic loads due to its instability $[100,101]$. In addition to the $\mathrm{pH}$ measurements, alkalinity measurements, which are essential for early detection of process instability, can be conducted via electrical conductivity measurements on real time basis $[102,103]$. Moreover, a Fourier Transform Infra-Red (FT-IR) spectrometer can be installed in the reactors to detect Chemical Oxygen Demand (COD), Total Organic Carbon (TOC), Volatile Fatty Acids (VFA), and Partial and Total Alkalinity (PA and TA) [104]. Ward et al. (2011) conducted a study in a pilot scale biogas plant to examine the feasibility of the measurements of Micro Gas Chromatography ( $\mu$-GC), Membrane Inlet Mass Spectroscopy (MIMS) in gas phase and with Near Infrared Spectroscopy (NIRS), $\mathrm{pH}$ in the liquid phase. The results showed that $\mu-\mathrm{GC}$ is suitable to determine $\mathrm{H}_{2}, \mathrm{CH}_{4}, \mathrm{H}_{2} \mathrm{~S}, \mathrm{~N}_{2}$ and $\mathrm{O}_{2}$ and MIMS can be used for determining $\mathrm{CH}_{4}, \mathrm{CO}_{2}$, $\mathrm{H}_{2} \mathrm{~S}$, reduced organic sulfur compounds and p-cresol. Moreover, NIRS can be used to estimate concentrations of acetate, propionate and VFAs [105]. A laboratory scale study showed that NIRS is suitable for the prediction of VFAs, propionic acid, Total Inorganic Carbon (TIC) and the ratio of VFA/TIC [106]. In addition, biogas composition can be determined by NIRS for different samples, which helps to design the operation biogas plant in an efficient way [107]. The replacement of off-line monitoring with an online automated system is needed to ensure sufficient monitoring at the biogas plants, especially in the rural areas [108].

\section{Biogas Plant Modelling}

There is still a lack of knowledge about the $\mathrm{AD}$ process and its reactions to the changes in the operational parameters, such as feedstock and temperature. Sufficient monitoring alone cannot help to implement predictive operation at the biogas plants through improved forecasting. Hence, detailed modelling of AD process is required. All the developed models 
over 50 years were examined by Salgado (2019) based on the time they developed and their complexity, and ADM1 was defined as the most complex model [109].

The first model for simulation of biogas plants was created by Andrews (1969), and most complex model is Anaerobic digestion model No 1 (ADM1), which performs a simulation of various substrates among all the models [109]. ADM1 created by Bastone et al. (2002) is the most widely used model in the past years [110]. The features of the models are summarized in Table 2.

Table 2. Created models for biogas plants.

\begin{tabular}{|c|c|c|}
\hline & Model & Description \\
\hline \multirow{6}{*}{$\begin{array}{c}1 \text { st } \\
\text { Generation }\end{array}$} & Andrews, (1969) & $\begin{array}{l}\text { This model shows that modelling of rate-limiting step gives information about whole process. } \\
\text { Bacterial inhibition can be explained with acid accumulation [109]. }\end{array}$ \\
\hline & Andrews and Graef, (1970) & $\begin{array}{l}\text { The dynamic simulation of enzymatic hydrolysis process is performed for complex organic } \\
\text { compounds [109]. }\end{array}$ \\
\hline & Hill \& Barth, (1977) & $\begin{array}{l}\text { This model was created to present stability in the AD process of the animal waste. With including } \\
\text { mass balances between volatile matter, volatile acids, soluble organics, two groups of bacteria, } \\
\text { cations, nitrogen, and carbon dioxide, pH value was calculated [111]. }\end{array}$ \\
\hline & Heyes \& Hall, (1981) & $\begin{array}{l}\text { A dynamic model was developed to present hydrogen inhibition of acetogenesis and } \mathrm{pH} \text { inhibition } \\
\text { of methanogenesis with using glucose as substrate [112]. }\end{array}$ \\
\hline & Hill, (1983) & $\begin{array}{l}\text { The model was developed the simulate steady state methane productivity (qualitative and } \\
\text { quantitively) in the AD process of animal waste [113]. }\end{array}$ \\
\hline & Mosey, (1983) & $\begin{array}{l}\text { Four bacterial groups were defined in the model for producing biogas through } \mathrm{AD} \text { of the glucose. In } \\
\text { the model, acetogenesis is defined as limiting step [109]. }\end{array}$ \\
\hline \multirow{4}{*}{$\begin{array}{l}\text { 2nd } \\
\text { Generation }\end{array}$} & Costello et al. (1991) & $\begin{array}{l}\text { Reactor process, physicochemical system and biological make-up were used in the system to create a } \\
\text { mathematical model. In addition lactic acid accumulation, product and } \mathrm{pH} \text { inhibition are included in } \\
\text { the model [114]. }\end{array}$ \\
\hline & Angelidaki et al. (1993) & $\begin{array}{l}\text { The model was developed to simulate anaerobic degradation of complex organic materials with } \\
\text { covering an enzymatic hydrolytic step, four bacterial steps and } 12 \text { chemical compounds [79]. }\end{array}$ \\
\hline & Vavilin et al. (1996) & $\begin{array}{l}\text { A model was developed to simulate hydrolysis (rate-limiting) stage of AD. The model includes } \\
\text { surface colonization of particles by hydrolytic bacteria and surface degradation [115]. }\end{array}$ \\
\hline & Husain, (1998) & $\begin{array}{l}\text { VFA-based Monod functions were used to define the death rates of acidogens and } \\
\text { methanogens [109]. }\end{array}$ \\
\hline \multirow{5}{*}{$\begin{array}{l}\text { 3rd } \\
\text { Generation }\end{array}$} & Bernard et al. (2001) & $\begin{array}{l}\text { Mass balance model was developed to identify parameters in the acidogenesis and methanogenesis } \\
\text { stages of the AD process. Electrochemical equilibria is used to include alkalinity in the model [116]. } \\
\text { Hydrolysis rate, acetotrophic methanogenesis and propionate degradation were specific focus of the } \\
\text { mathematical model created, which simulated dynamic behavior of both mesophilic and } \\
\text { thermophilic AD [117]. }\end{array}$ \\
\hline & Bastone et al. (2002) & $\begin{array}{l}\text { ADM1 includes both biochemical and physicochemical processes. } 26 \text { dynamic state concentration } \\
\text { variables, } 8 \text { implicit algebraic variables and } 32 \text { concentration state variables are performed in this } \\
\text { generalized AD model [118]. }\end{array}$ \\
\hline & Zaher et al. (2009) & $\begin{array}{l}\text { The model was created to understand microbial activity based on the availability of the } \\
\text { macronutrients (C, H, N, O, P, and } S \text { ) and thermodynamics of acidogenesis and methanogenesis [119]. }\end{array}$ \\
\hline & Rajendran et al. (2014) & $\begin{array}{l}46 \text { reactions (for inhibition, rate-kinetics, } \mathrm{pH} \text {, ammonia, volume, loading rate, and retention time) are } \\
\text { performed in the model to predict biogas production from any substrate and at any operation } \\
\text { condition with using Aspen Plus [120]. }\end{array}$ \\
\hline & Arzate et al. (2015) & $\begin{array}{l}\text { This model represents combination of Life Cycle Assessment (LCA) characterization and } \\
\text { mathematical model of the process performance, which can supply decrease in the environmental } \\
\text { impact of AD processes. To perform LCA and mathematical model, Simapro and ASPEN were used } \\
\text { respectively [121]. }\end{array}$ \\
\hline \multirow{5}{*}{$\begin{array}{l}\text { Statistical } \\
\text { Models }\end{array}$} & Barampouti et al. (2005) & $\begin{array}{l}\text { The model was created to predict biogas production of UASB (Up flow Anaerobic Sludge Blanket) } \\
\text { with examining } 17 \text { parameters from the two-year operation data of the potato wastewater treatment } \\
\text { plant [122]. }\end{array}$ \\
\hline & Nopharatana et al. (2007) & $\begin{array}{l}\text { The model was created to simulate biological reactions in AD from Municipal Solid Waste (MSW) } \\
\text { with considering it in two fractions; soluble and insoluble. Contois, Monod and Gompertz equations } \\
\text { were implemented in the model [123]. }\end{array}$ \\
\hline & Yusuf and Ify, (2011) & $\begin{array}{l}\text { The model was created to predict maximum and ultimate bigas yield and ultimate methane yield in } \\
\text { co-digestion of cow dung and water hyacinth based on the first order kinetic model [124]. }\end{array}$ \\
\hline & $\begin{array}{l}\text { Syaichurrozi and } \\
\text { Sumardino, (2013) }\end{array}$ & $\begin{array}{l}\text { Kinetic model for determining biogas production was developed with modifying equation of } \\
\text { Gompertz. Effect of the COD/N ratio on the kinetic model was studied [125]. }\end{array}$ \\
\hline & Brule et al. (2014) & $\begin{array}{l}\text { The model was created to optimize BMP assays. It supplies quality control of the BMP assays, } \\
\text { interpretation of reaction kinetics and estimation of methane yield [126]. }\end{array}$ \\
\hline
\end{tabular}




\section{Process Optimization through Implementation of Artificial Intelligence (Predictive Analytics)}

Since it is possible to get time delay through offline monitoring, online monitoring is getting more attractive day by day. Continuous monitoring can be considered the main condition for process optimization and quality control, since it allows us tracking of real time data and gives us time analyze and react. That is why there have been several studies about online monitoring and its benefits on natural systems [127].

Analyzing and getting valuable outputs from a huge amount of gathered data could be possible with just mathematical and statistical methods. These analyses also allow for predictive maintenance and continuous process improvements, which gives not only flexibility in energy production but also a stable process [19,128].

Standardizing the requirements of process optimization is not possible in dynamic systems. Living organisms cannot be defined as stable systems which is why it is not possible to track them in conditional monitoring methods. A variety of characters and uncontrollable environment conditions bring indifferent demands on feeding and maintaining in AD. This dynamic behavior can be monitored and measured by modern methods and interpreted accurately [129].

There have already been some studies about statistical methods and AI in the area of living (biological) systems. In order to be able to take advantageous of predictive analytics, it is obligatory to get a sufficient amount of data to work with. Especially in dynamic conditions such as biogas plants, where there are not only internal parameters but also external parameters affecting the process, real time monitoring has enormous importance. Online monitoring comes with the requirement of parameter definition that shall be monitored, tracked and analyzed [99].

With gathered data it is possible to launch predictive analytics for process optimization, which also gives the opportunity to search possible optimization scenarios in natural sciences. Wahmkow has studied the usage of neural networks and fuzzy logic in his work. As an optimum solution to build a driver for biogas production, a combination of Neural Network, Fuzzy Logic and optimization was suggested. In the end it was claimed that with the usage of automated controller techniques, technical and ecological goals could be achieved. In this study it was anticipated that the proof of concept is missing. With the simulated model of the real reactor, it was aimed to have a tested controller for feeding on an industrial scale. It is claimed that it is possible to get flexible feeding and energy production [129]. In similar direction, Bhuiyan et al. (2019) [130] have studied the feasibility of having a sustainable and affordable way to produce renewable energy at any scale for all end level users in the world. In this model it was aimed to find a new method to produce clean energy with the help of modern technology like IOT and AI [129,131]. Moreover, Olabi et al. (2020) aimed at maximizing the methane production from wastepaper via the integration of AI to the monitoring [14].

Fuzzy logic-based modelling and modern optimization were proposed in this study. With the help of the fuzzy model, the increase the methane yield under some predefined circumstances was achieved.

As mentioned above, it is not possible to ignore the effect of external influences and various process disturbances on the optimization of agricultural and industrial biogas plants. Because of an insufficient level of real time monitoring, most of the biogas plants are operated manually, which brings the need for the development of new methods to increase the productivity. With this aim, advantages and usage of computational and AI such as Genetic Algorithms and Particle Swarm Optimization were studied by Wolf et al. (2009) to increase the productivity and to gain flexibility in these systems. Results show that an improvement of up to $20 \%$ in biogas production and substrate reduction can be achieved when compared to conventional manual operation [132].

Optimizing AD through existing recent artificial techniques has been the scope of also Ramachandran et al. (2019) work. He analyzed the advantages and disadvantages of the techniques and their application areas in biogas plants. The optimization of AD with its non- 
linear character due to the complexity and number of parameters that play an important role allows us to use AI to find out the optimum model for our problem statement, which is making biogas production more effectively to be able to compute with other renewable energy sources [110]. Another example of using AI on an industrial scale can be seen by work of Tumer and Edebali [133]. In this study, a wastewater treatment plant in Konya, Turkey was analyzed by using artificial neural network with different architectures with daily data obtained in four months. As a conclusion, maximum correlation coefficient was reached with Artificial Neural Network (ANN), which means that ANN could be used to make predictions in such a system for operating plants.

It is obvious that ANN are also becoming a powerful tool in the field of biogas production. In spite of the fact that biogas systems are very different, considering technological differences and differences of input substrates in areas such as municipal, agriculture, industry, water treatment plants etc., ANNs show a high degree of usability. The results of the summarized studies show high prediction accuracy and usefulness of the ANN which thereby become strong competition to conventional methods of measurement and data processing. Even more, the fusion of both methods and the complementary functioning of soft and hard computing brings many benefits beyond the capabilities of each individual method [134].

There have also been machine learning applications in the natural sciences, that also enable intelligent decision-making systems, and artificial and computational intelligence in the world of data science. Daily time series data in a wastewater treatment plant were used as input for developing a support vector machine model by Manu and Thalla (2017), and it was observed that is possible to define the relation between dependent and independent variables with help of machine learning algorithms [135,136].

Machine Learning models give different approaches to predictive analytics such as regression and classification models. As Wang and Long mentioned in their research in December 2019, recent developed algorithms such as ANN, support vector machine (SVM), random forest, logistic regression multiclass (GLMNET) have been used as both regression and classification models in their study to define sufficient parameters and use prediction about methane production in anaerobic digestion [137].

Last but not least there have been studies related to predictive maintenance with more modern algorithms and approaches. In 2019, different machine learning models such as logistic regression, support vector machine, random forest, extreme gradient boosting (XGBoost), and k-nearest neighbors regression were compared with a dataset provided by two major Chinese biogas plants on a daily basis. The aim of this study is developing a user interface with machine learning to be able to improve productivity in industrial scale. This approach can be also considered as a concrete and industrial usage of predictive analytics [138].

As can also be seen in the abovementioned studies, it is possible to get the benefit of predictive analytics and artificial intelligence in real life with the help of data science. It requires multi-functional disciplines from raw data to get insights of it, such as sensor technique, IoT, data warehousing, database and formatting, statistic, machine learning and control units like programmable logic controller; it can be grouped in three main categories: computer Science/IT, Math/Statistics and Domains/Business knowledge [129,139-142].

Although there are tremendous developments in sensor technique, automation systems and data monitoring in system engineering and even usage of programmable logic controller for feeding in several industrial scales, it is still not possible to run a biogas plant automatically. Predictive analytics, data science, AI and Proportional Integral Derivative (PID), which allows closed-loop control methods could have already been applied in laboratory scales. In addition, there is still a need for an extended research for the industrial scale. 


\section{Discussion}

It would be wrong to expect that the usage of predictive analytics or artificial intelligence represents a direct monetary value. These approaches should be seen as a tool for the continuous improvement and operational excellence through cost reduction via increased productivity and predictive maintenance in industry [143-145]. Real Time Optimization can be performed in three stages: (a) process modelling, (b) numerical optimization using the process model and (c) application of the model-based inputs into the plant $[146,147]$. To do so, the implementation of future oriented sensors and data collection technologies are required.

In order to have a clear road map, it has to be understood how internet of things helps in this process. The basis of the IoT (Internet of Things) is coming from CyberPhysical Systems (CPS). These are objects, devices, buildings, production facilities, logistic components, etc., which are integrated through recording the environment via sensors, evaluating and storing the recorded data, communicating via Internet and/or influencing the physical world/environment via actuators in principal of embedded systems $[139,144]$.

According to VDMA (Mechanical Engineering Industry Association Germany) Guidelines, a roadmap for digitalization processes has to include following steps:

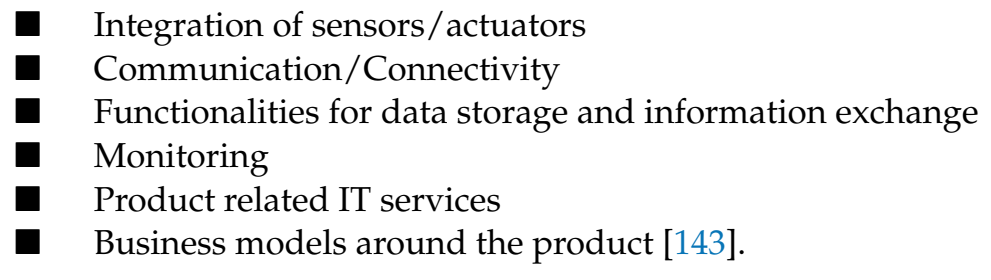

In light of the guideline from VDMA, possible steps for implementing predictive analytics and artificial intelligence in $\mathrm{AD}$ could be shown as follows:

1. Physical device; fermenter, substrate storage, biogas storage

2. Sensor/ Actuator; temperature, pressure, $\mathrm{pH}, \mathrm{CO}_{2}, \mathrm{CH}_{4}$, NIR sensor

3. Data/ Connection; data warehousing, data formatting, online monitoring

4. Analytics; data preprocessing, data analytics, machine learning, predictive analytics

5. Service; productivity, predictive maintenance, decision-making systems, automated feeding $[143,145]$.

Moreover, demand-based and resource-based operation at the biogas plants can be performed with integration of $\mathrm{AI}$ into the operation. External parameters can be considered while planning the integration of $\mathrm{AI}$ into AD process; weather conditions, feedstock sources, demand for electricity, heat, biofuel and fertilizer (see Figure 4). An improved communication between resources supply and the product demand can supply efficient and flexible energy production. Instead of storing the ready consumption energy, it is sensible and efficient to store biogas at the plants to be processed into electricity in case of demand.

Demand-based biogas production can be achieved with the implementation of flexible feeding without the requirement for additional gas storage [148]. The weather conditions affect both heat losses through fermenter and storage conditions of the feedstock $[86,149,150]$. A continuous data transfer and data analysis can supply predictive operation of biogas plants with forecasting the efficiency of the process, dependent on the quality of substrate and heat demand based on the heat losses.

In order to determine demand precisely, continuous data transfer between market demand for electricity, heat, biofuel, fertilizer can be used for efficient, and demandbased operation of biogas plants. Moreover, with using satellite CHPs, a decrease in the investment cost can be achieved [151,152].

Due to the complexity of the biogas production system and flexibility in the production, improved monitoring at the biogas plants is required. In the figure below (Figure 4), an example biogas plant was represented with the parameters, which should be monitored and controlled in real time. Firstly, the quality and quantity of input material should 
be determined, which has a direct effect on biogas quality. In addition, flowrates in the pipelines between the components of the plant should be measured to create a mass transfer model of the biogas plant. In order to have reliable data about the operation of each single reactor, biogas content and amount should be determined for each reactor separately rather than conducting one measurement for whole biogas plant. The efficiency of physical and biochemical reactions in the reactors can be determined with analyzing the parameters, such as TS, VS, VFA, $\mathrm{pH}$, pressure (p), $\mathrm{NH}_{4}-\mathrm{N}^{+}, \mathrm{VOA} / \mathrm{TIC}$ and inhibitors and toxins. On-line monitoring of several parameters at the biogas plant in both substrate storages and in the reactors can be performed by NIRS $[106,153,154]$.

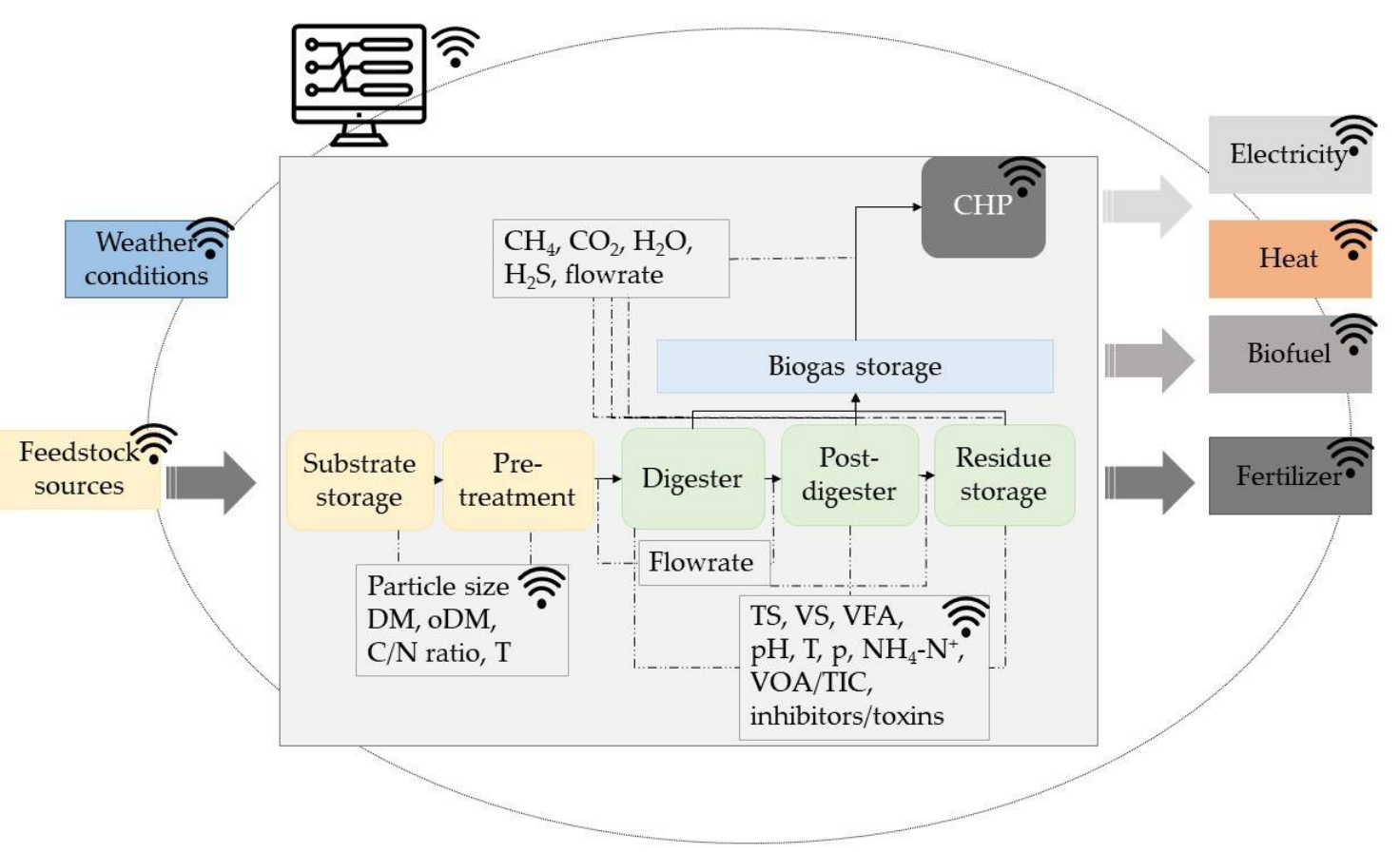

Figure 4. Integration of $\mathrm{AI}$ into the $\mathrm{AD}$ operation for flexible and efficient production. p: pressure.

\section{Conclusions}

Artificial Intelligence has been investigated and implemented in several processes. The positive effect of Artificial Intelligence to the bioprocess monitoring is not negligible. Integration of Artificial Intelligence into the biogas production process is possible with big data gathering. Improved sensor technologies are to supply sufficient data for finding the correlation between the parameters and creating the operational models, which are going to supply predictive and flexible operation of the biogas plants. Thus, possible failures will be hindered, and demand-/ resource-based production will be realized.

As mentioned before, there have been a lot of studies in both academical and industrial environments about process optimization in different areas through lean philosophy and Six Sigma for years. The proven benefit of these approaches brings us to the search for a better, more efficient and more modern way to achieve operational excellence. The common point of all these improvement perspectives is the data itself. For lean management, lean production, six sigma and all of the operational excellence tools, the collected data is needed and analyzed for better understanding of the process and relation between parameters [155].

Creating a decision-making and automated AD system in more tangible levels for the industry with the base of conventional improvement cultures and methodology such as lean philosophy is one of the main conditions for a higher contribution of biogas plants in renewable energy. 
Author Contributions: Conceptualization, S.C., S.O.C. and K.K.; methodology, S.C. and N.W.; data curation, S.C. and K.K.; writing-original draft preparation, S.C., S.O.C., N.W. and K.K.; writingreview and editing, S.C., S.O.C., N.W. and I.S.; visualization, S.C., S.O.C. and I.S.; supervision, N.W. and K.K.; project administration, K.K. All authors have read and agreed to the published version of the manuscript.

Funding: This research received no external funding.

Institutional Review Board Statement: Not applicable.

Informed Consent Statement: Not applicable.

Data Availability Statement: Data sharing not applicable.

Acknowledgments: Publishing fees were supported by Funding Programme *Open Access Publishing* of Hamburg University of Technology. Thanks to German Academic Exchange Service (DAAD) for their scholarship to the researcher (S.O.C.).

Conflicts of Interest: The authors declare no conflict of interest.

\section{References}

1. Our World in Data. Available online: https:/ / ourworldindata.org/energy (accessed on 17 June 2020).

2. International Energy Agency. Germany 2020 Energy Policy Review; IEA: Paris, France, 2020.

3. International Renewable Energy Agency. Trends in Renewable Energy. Available online: http://resourceirena.irena.org (accessed on 12 September 2020).

4. Scopus. Analyzed Research Results. Available online: https://www.scopus.com (accessed on 17 June 2020).

5. European Commission. New Study Focuses on Potential of Biogas as Source of Clean Production. Available online: https: / / ec.europa.eu/energy/news/new-study-focuses-potential-biogas-source-clean-energy (accessed on 17 June 2020).

6. Banja, M.; Jégard, M.; Motola, V.; Sikkema, R. Support for biogas in the EU electricity sector-A comparative analysis. Biomass Bioenergy 2019, 128, 105313. [CrossRef]

7. European Commission. Renewable Energy_Recast to 2030 (RED II); European Commission: Brussels, Belgium, 2016.

8. Rutz, D.; Janssen, R.; Mergner, R. Sustainable Heat Use of Biogas Plants: A Handbook; WIP Renewable Energies: Munich, Germany, 2015; ISBN 3936338353.

9. Nsair, A.; Onen Cinar, S.; Alassali, A.; Abu Qdais, H.; Kuchta, K. Operational Parameters of Biogas Plants: A Review and Evaluation Study. Energies 2020, 13, 3761. [CrossRef]

10. Salehi, H.; Burgueno, R. Emerging artificial intelligence methods in structural engineering. Eng. Struct. 2018, 171, 170-189. [CrossRef]

11. Venkatasubramanian, V. The promise of artificial intelligence in chemical engineering: Is it here, finally? AIChE J. 2019, 65, 466-478. [CrossRef]

12. Nasiri, S.; Khosravani, M.R.; Weinberg, K. Fracture mechanics and mechanical fault detection by artificial intelligence methods: A review. Eng. Fail. Anal. 2017, 81, 270-293. [CrossRef]

13. Kana, E.G.; Oloke, J.K.; Lateef, A.; Adesiyan, M.O. Modeling and optimization of biogas production on saw dust and other co-substrates using artificial neural network and genetic algorithm. Renew. Energy 2012, 46, 276-281. [CrossRef]

14. Olabi, A.; Nassef, A.M.; Rodriguez, C.; Abdelkareem, M.A.; Rezk, H. Application of artificial intelligence to maximize methane production from waste paper. Int. J. Energy Res. 2020, 44, 9598-9608. [CrossRef]

15. Lauer, M.; Leprich, U.; Thrän, D. Economic assessment of flexible power generation from biogas plants in Germany's future electricity system. Renew. Energy 2020, 146, 1471-1485. [CrossRef]

16. Balussou, D.; McKenna, R.; Möst, D.; Fichtner, W. A model-based analysis of the future capacity expansion for German biogas plants under different legal frameworks. Renew. Sust. Energ. Rev. 2018, 96, 119-131. [CrossRef]

17. Daniel-Gromke, J.; Kornatz, P.; Dotzauer, M.; Stur, M.; Denysenko, V.; Stelzer, M.; Hahn, H.; Krautkremer, B.; von Bredow, H.; Antonow, K. Guide to Making Electricity Provision More Flexible in Biogas Plants (LF Flex); DBFZ Deutsches Biomasse Forschungszentrum: Leipzig, Germany, 2019.

18. Yan, J.; Meng, Y.; Lu, L.; Li, L. Industrial big data in an industry 4.0 environment: Challenges, schemes, and applications for predictive maintenance. IEEE Access 2017, 5, 23484-23491. [CrossRef]

19. Mauky, E.; Weinrich, S.; Jacobi, H.-F.; Nägele, H.-J.; Liebetrau, J.; Nelles, M. Demand-driven biogas production by flexible feeding in full-scale-Process stability and flexibility potentials. Anaerobe 2017, 46, 86-95. [CrossRef] [PubMed]

20. Lauer, M.; Thrän, D. Flexible biogas in future energy systems-Sleeping beauty for a cheaper power generation. Energies 2018, 11, 761. [CrossRef]

21. FNR. Guide to Biogas_From Production to Use; Deutsche Gesellschaft für Internationale Zusammenarbeit: Eschborn, Germany, 2010.

22. Achinas, S.; Martherus, D.; Krooneman, J.; Euverink, G.J.W. Preliminary Assessment of a Biogas-based Power Plant from Organic Waste in the North Netherlands. Energies 2019, 12, 4034. [CrossRef]

23. Samer, M. Biogas Plant Constructions; Biogas, S.K., Ed.; Intech Open: London, UK, 2012; pp. 343-368. 
24. Rohstoffe, F.N. Guide Biogas: From extraction to use. In Bioenergy; Deutsche Gesellschaft für Internationale Zusammenarbeit: Eschborn, Germany, 2016; pp. 21-113.

25. Scarlat, N.; Dallemand, J.-F.; Fahl, F. Biogas: Developments and perspectives in Europe. Renew. Energy 2018, 129, 457-472. [CrossRef]

26. Wang, P.; Wang, H.; Qiu, Y.; Ren, L.; Jiang, B. Microbial characteristics in anaerobic digestion process of food waste for methane production-A review. Bioresour. Technol. 2018, 248, 29-36. [CrossRef] [PubMed]

27. Adekunle, K.F.; Okolie, J.A. A Review of Biochemical Process of Anaerobic Digestion. ABB 2015, 6, 205-212. [CrossRef]

28. Schnürer, A.; Jarvis, Å. Microbiological handbook for biogas plants. Swedish Waste Management U2009:03 Swedish Gas Centre Report 207; Avfall Sverige and Svenskt Gastekniskt Center AB: Malmö, Sweden, 2009; pp. 1-74.

29. Caballero-Arzápalo, N. Investigations on the anaerobic degradation process of selected waste substrates with the help of special microorganisms and enzymes. Energies 2015, 13, 3761.

30. HHU. Influencing Factors: Enzymatic Activity and Temperature. Available online: https://www3.hhu.de (accessed on 24 June 2020).

31. Mir, M.A.; Hussain, A.; Verma, C. Design considerations and operational performance of anaerobic digester: A review. Cogent Eng. 2016, 3. [CrossRef]

32. Gerardi, M.H. The Microbiology of Anaerobic Digesters; Wiley: Hoboken, NJ, USA, 2003. [CrossRef]

33. Hanum, F.; Yuan, L.C.; Kamahara, H.; Aziz, H.A.; Atsuta, Y.; Yamada, T.; Daimon, H. Treatment of sewage sludge using anaerobic digestion in Malaysia: Current state and challenges. Front. Energy Res. 2019, 7, 19. [CrossRef]

34. Yan, Z.; Song, Z.; Li, D.; Yuan, Y.; Liu, X.; Zheng, T. The effects of initial substrate concentration, C/N ratio, and temperature on solid-state anaerobic digestion from composting rice straw. Bioresour. Technol. 2015, 177, 266-273. [CrossRef]

35. Weiland, P. Biogas production: Current state and perspectives. Appl. Microbiol. Biotechnol. 2010, 85, 849-860. [CrossRef] [PubMed]

36. Bachmann, E.S.N. Design and engineering of biogas plants. In The Biogas Handbook; Elsevier: Amsterdam, The Netherlands, 2013; pp. 191-211.

37. Chen, Y.; Cheng, J.J.; Creamer, K.S. Inhibition of anaerobic digestion process: A review. Bioresour. Technol. 2008, 99, 4044-4064. [CrossRef] [PubMed]

38. Azman, S.; Khadem, A.F.; Plugge, C.M.; Stams, A.J.M.; Bec, S.; Zeeman, G. Effect of humic acid on anaerobic digestion of cellulose and xylan in completely stirred tank reactors: Inhibitory effect, mitigation of the inhibition and the dynamics of the microbial communities. Appl. Microbiol. Biotechnol. 2017, 101, 889-901. [CrossRef] [PubMed]

39. Azman, S.; Khadem, A.F.; van Lier, J.B.; Zeeman, G.; Plugge, C.M. Presence and role of anaerobic hydrolytic microbes in conversion of lignocellulosic biomass for biogas production. Crit. Rev. Environ. Sci. Technol. 2015, 45, 2523-2564. [CrossRef]

40. Cazier, E.A.; Trably, E.; Steyer, J.-P.; Escudié, R. Biomass hydrolysis inhibition at high hydrogen partial pressure in solid-state anaerobic digestion. Bioresour. Technol. 2015, 190, 106-113. [CrossRef]

41. Amha, Y.M.; Anwar, M.Z.; Brower, A.; Jacobsen, C.S.; Stadler, L.B.; Webster, T.M.; Smith, A.L. Inhibition of anaerobic digestion processes: Applications of molecular tools. Bioresour. Technol. 2018, 247, 999-1014. [CrossRef]

42. Sun, C.; Cao, W.; Banks, C.J.; Heaven, S.; Liu, R. Biogas production from undiluted chicken manure and maize silage: A study of ammonia inhibition in high solids anaerobic digestion. Bioresour. Technol. 2016, 218, 1215-1223. [CrossRef]

43. Dasa, K.T.; Westman, S.Y.; Millati, R.; Cahyanto, M.N.; Taherzadeh, M.J.; Niklasson, C. Inhibitory effect of long-chain fatty acids on biogas production and the protective effect of membrane bioreactor. BioMed Res. Int. 2016, 2016, 1-9.

44. Palatsi, J.; Laureni, M.; Andrés, M.V.; Flotats, X.; Nielsen, H.B.; Angelidaki, I. Strategies for recovering inhibition caused by long chain fatty acids on anaerobic thermophilic biogas reactors. Bioresour. Technol. 2009, 100, 4588-4596. [CrossRef]

45. Kougias, P.G.; Angelidaki, I. Biogas and its opportunities-A review. Front. Environ. Sci. Eng. 2018, 12, 14. [CrossRef]

46. Yenigün, O.; Demirel, B. Ammonia inhibition in anaerobic digestion: A review. Process Biochem. 2013, 48, 901-911. [CrossRef]

47. Lauterböck, B.; Ortner, M.; Haider, R.; Fuchs, W. Counteracting ammonia inhibition in anaerobic digestion by removal with a hollow fiber membrane contactor. Water Res. 2012, 46, 4861-4869. [CrossRef] [PubMed]

48. Procházka, J.; Dolejš, P.; Máca, J.; Dohányos, M. Stability and inhibition of anaerobic processes caused by insufficiency or excess of ammonia nitrogen. Appl. Microbiol. Biotechnol. 2012, 93, 439-447. [CrossRef] [PubMed]

49. Sawayama, S.; Tada, C.; Tsukahara, K.; Yagishita, T. Effect of ammonium addition on methanogenic community in a fluidized bed anaerobic digestion. J. Biosci. Bioeng. 2004, 97, 65-70. [CrossRef]

50. Hilton, B.L.; Oleszkiewicz, J.A. Sulfide-induced inhibition of anaerobic digestion. J. Environ. Eng. 1988, 114, 1377-1391. [CrossRef]

51. Zhang, C.; Su, H.; Tan, T. Batch and semi-continuous anaerobic digestion of food waste in a dual solid-liquid system. Bioresour. Technol. 2013, 145, 10-16. [CrossRef]

52. Mudhoo, A.; Kumar, S. Effects of heavy metals as stress factors on anaerobic digestion processes and biogas production from biomass. Int. J. Environ. Sci. Technol. 2013, 10, 1383-1398. [CrossRef]

53. Kumar, A.; Miglani, P.; Gupta, R.K.; Bhattacharya, T.K. Impact of Ni (II), Zn (II) and Cd (II) on biogassification of potato waste. J. Environ. Biol. 2006, 27, 61-66.

54. Luning, L.; van Zundert, E.H.M.; Brinkmann, A.J.F. Comparison of dry and wet digestion for solid waste. Water Sci. Technol. 2003, $48,15-20$. [CrossRef] 
55. Chiumenti, A.; Chiumenti, R.; da Borso, F.; Limina, S. Comparison between Dry and Wet Fermentation of Biomasses as Result of the Monitoring of Full Scale Plants. In Proceedings of the ASABE Annual International Meeting, Dallas, TX, USA, 29 July-1 August 2012.

56. Morken, J.; Gjetmundsen, M.; Fjørtoft, K. Determination of kinetic constants from the co-digestion of dairy cow slurry and municipal food waste at increasing organic loading rates. Renew. Energy 2018, 117, 46-51. [CrossRef]

57. Christou, M.L.; Vasileiadis, S.; Kalamaras, S.D.; Karpouzas, D.G.; Angelidaki, I.; Kotsopoulos, T.A. Ammonia-induced inhibition of manure-based continuous biomethanation process under different organic loading rates and associated microbial community dynamics. Bioresour. Technol. 2020, 320, 124323. [CrossRef] [PubMed]

58. Mahdy, A.; Bi, S.; Song, Y.; Qiao, W.; Dong, R. Overcome inhibition of anaerobic digestion of chicken manure under ammoniastressed condition by lowering the organic loading rate. Bioresour. Technol. Rep. 2020, 9, 100359. [CrossRef]

59. Ziganshin, A.M.; Schmidt, T.; Lv, Z.; Liebetrau, J.; Richnow, H.H.; Kleinsteuber, S.; Nikolausz, M. Reduction of the hydraulic retention time at constant high organic loading rate to reach the microbial limits of anaerobic digestion in various reactor systems. Bioresour. Technol. 2016, 217, 62-71. [CrossRef] [PubMed]

60. Wijekoon, K.C.; Visvanathan, C.; Abeynayaka, A. Effect of organic loading rate on VFA production, organic matter removal and microbial activity of a two-stage thermophilic anaerobic membrane bioreactor. Bioresour. Technol. 2011, 102, 5353-5360. [CrossRef] [PubMed]

61. Nsair, A.; Cinar, S.Ö.; Qdais, H.A.; Kuchta, K. Optimizing the performance of a large scale biogas plant by controlling stirring process: A case study. Energy Convers. Manag. 2019, 198, 111931. [CrossRef]

62. Romsaiyud, A.; Songkasiri, W.; Nopharatana, A.; Chaiprasert, P. Combination effect of pH and acetate on enzymatic cellulose hydrolysis. J. Environ. Sci. 2009, 21, 965-970. [CrossRef]

63. Siegert, I.; Banks, C. The effect of volatile fatty acid additions on the anaerobic digestion of cellulose and glucose in batch reactors. Process Biochem. 2005, 40, 3412-3418. [CrossRef]

64. Angelidaki, I.; Ahring, B.K. Thermophilic anaerobic digestion of livestock waste: The effect of ammonia. Appl. Microbiol. Biotechnol. 1993, 38, 560-564. [CrossRef]

65. Lin, Q.; de Vrieze, J.; Li, C.; Li, J.; Li, J.; Yao, M.; Hedenec, P.; Li, H.; Li, T.; Rui, J.; et al. Temperature regulates deterministic processes and the succession of microbial interactions in anaerobic digestion process. Water Res. 2017, 123, 134-143. [CrossRef]

66. Önen, S.; Nsair, A.; Kuchta, K. Innovative operational strategies for biogas plant including temperature and stirring management. Waste Manag. Res. 2019, 37, 237-246. [CrossRef]

67. Cinar, S.Ö.; Kuchta, K. Evaluation of Temperature Changes in Anaerobic Digestion Process. Detritus 2020, 10, 11-18. [CrossRef]

68. Hans, B. Enzyme Kinetics Principles and Methods; Wiley Vch Valag: Wheinheim, Germany, 2008.

69. Al Seadi, T.; Rutz, D.; Prassl, H.; Köttner, M.; Finsterwalder, T.; Volk, S.; Janssen, R. Biogas Handbook; University of Southern Denmark Esbjerg: Esbjerg, Denmark, 2008.

70. Sarker, S.; Lamb, J.J.; Hjelme, D.R.; Lien, K.M. A Review of the Role of Critical Parameters in the Design and Operation of Biogas Production Plants. Appl. Sci. 2019, 9, 1915. [CrossRef]

71. Drogs, B. Biogas Process Monitoring-Techniques and Recommendations. Available online: http://task37.ieabioenergy. com/files/daten-redaktion/download/publications/Workshops/2013_Switzerland/4_Biogas\%20process\%20monitoring techniques\%20and\%20recommendations_Drosg.pdf (accessed on 1 July 2020).

72. Drosg, B. Process Monitoring in Biogas Plants; IEA Bioenergy: Paris, France, 2013; ISBN 1910154024.

73. Deng, L.; Liu, Y.; Wang, W. Biogas Technology; Springer: Singapore, 2020; pp. 109-156. ISBN 978-981-15-49-40-3.

74. Anukam, A.; Mohammadi, A.; Naqvi, M.; Granström, K. A review of the chemistry of anaerobic digestion: Methods of accelerating and optimizing process efficiency. Processes 2019, 7, 504. [CrossRef]

75. Ma, J.; Frear, C.; Wang, Z.-w.; Yu, L.; Zhao, Q.; Li, X.; Chen, S. A simple methodology for rate-limiting step determination for anaerobic digestion of complex substrates and effect of microbial community ratio. Bioresour. Technol. 2013, 134, 391-395. [CrossRef] [PubMed]

76. Singh, P.K.; Verma, S.K.; Ojha, S.K.; Panda, P.K.; Srichandan, H.; Jha, E.; Mishra, S. Intrinsic molecular insights to enhancement of biogas production from kitchen refuse using alkaline-microwave pretreatment. Sci. Rep. 2019, 9, 1-12. [CrossRef] [PubMed]

77. Rojas Reina, C.J. Simulation and Modeling of the Anaerobic Process of Biogas Production with Different Substrates; Hamburg University of Technology: Hamburg, Germany, 2014.

78. Satyam, S.; Himanshu, S.; Tushar, S.; Shubham, B.; Prasad, K. Anaerobic Digestion of Water Hyacinth; International Journal of Innovative Research in Science and Engineering: Balewadi Pune, India, 2017.

79. Angelidaki, I.; Ellegaard, L.; Ahring, B.K. A mathematical model for dynamic simulation of anaerobic digestion of complex substrates: Focusing on ammonia inhibition. Biotechnol. Bioeng. 1993, 42, 159-166. [CrossRef]

80. Singhal, S.; Sharma, R.; Sharma, M.; Agarwal, S.; Singhal, N. Application of Remote Sensing in the Monitoring of Biogas Production; Springer: Singapore, 2017.

81. Biogas World. Troubleshooting: Biogas Plants Problems: What Factors can Cause Biogas Plant Problems? Available online: https: / / www.biogasworld.com/biogas-plant-troubleshooting/ (accessed on 8 October 2020).

82. Svensson, K.; Paruch, L.; Gaby, J.C.; Linjordet, R. Feeding frequency influences process performance and microbial community composition in anaerobic digesters treating steam exploded food waste. Bioresour. Technol. 2018, 269, 276-284. [CrossRef] 
83. De Francisci, D.; Kougias, P.G.; Treu, L.; Campanaro, S.; Angelidaki, I. Microbial diversity and dynamicity of biogas reactors due to radical changes of feedstock composition. Bioresour. Technol. 2015, 176, 56-64. [CrossRef]

84. Rohstoffe eV, F.-F.N. Leitfaden Biogas-Von der Gewinnung zur Nutzung. Fachagentur Nachwachsende Rohstoffe eV(Ed). Available online: https:/ / biogas.fnr.de/projekte/projektuebersicht (accessed on 15 August 2020).

85. Jabłoński, S.; Rodowicz, P.; Łukaszewicz, M. Methanogenic archaea database containing physiological and biochemical characteristics. Int. J. Syst. Evol. Microbiol. 2015, 65, 1360-1368. [CrossRef]

86. Gerber, M. Integrated Material and Energetic Modeling of the Biogas Formation Process; Ruhr University Bochum: Bochum, Germany, 2009.

87. Besgen, S. Energy and Material Conversion in Biogas Plants—Results of Technical Measurements on Agricultural Biogas Plants in the Rhineland; Universitäts-und Landesbibliothek Bonn: Bonn, Germany, 2005.

88. Für Umwelt, B.L. Biogashandbuch Bayern-Materialienband. Kap 2007, 1, 20.

89. Roubík, H.; Mazancová, J.; Banout, J.; Verner, V. Addressing problems at small-scale biogas plants: A case study from central Vietnam. J. Clean. Prod. 2016, 112, 2784-2792. [CrossRef]

90. Trávníček, P.; Kotek, L.; Junga, P.; Vítěz, T.; Drápela, K.; Chovanec, J. Quantitative analyses of biogas plant accidents in Europe. Renew. Energy 2018, 122, 89-97.

91. Wiese, J.; König, R. Application Report, Laboratory Analysis \& Process Analysis Biogas Plant Monitoring, Monitoring of digesters in biogas plants; HACH LANGE GmbH: Düsseldorf, Germany, 2007.

92. Ghanavati, H. Biogas Production Systems: Operation, Process Control, and Troubleshooting; Springer: Berlin/Heidelberg, Germany, 2018; pp. 199-219.

93. Lindorfer, H.; Demmig, C. Foam formation in biogas plants-a survey on causes and control strategies. Chem. Eng. Technol. 2016, 39, 620-626. [CrossRef]

94. Gaida, D.; Wolf, C.; Bongards, M. Feed control of anaerobic digestion processes for renewable energy production: A review. Renew. Sustain. Energy Rev. 2017, 68, 869-875. [CrossRef]

95. Nguyen, D.; Gadhamshetty, V.; Nitayavardhana, S.; Khanal, S.K. Automatic process control in anaerobic digestion technology: A critical review. Bioresour. Technol. 2015, 193, 513-522. [CrossRef]

96. Bochmann, G. Monitoring and Process Control of Biogas Plants. Available online: https://s3-ap-southeast-2.amazonaws.com/ piano.revolutionise.com.au/cups/bioenergy/files/2whnulfvy6ubaoid.pdf (accessed on 6 July 2020).

97. Lamb, J.J.; Bernard, O.; Sarker, S.; Lien, K.M.; Hjelme, D.R. Perspectives of optical colourimetric sensors for anaerobic digestion. Renew. Sust. Energ. Rev. 2019, 111, 87-96. [CrossRef]

98. Wu, D.; Li, L.; Zhao, X.; Peng, Y.; Yang, P.; Peng, X. Anaerobic digestion: A review on process monitoring. Renew. Sust. Energ. Rev. 2019, 103, 1-12. [CrossRef]

99. Boe, K. Online Monitoring and Control of the Biogas Process; Technical University of Denmark: Kongens Lyngby, Denmark, 2006; pp. $25-28$.

100. Wolf, C.; Gaida, D.; Bongards, M. Online-Measurement Systems for Agricultural and Industrial AD Plants-A Review and Practice Test; Köln University of Applied Science: Köln, Germany, 2014.

101. Alessandro, C.; da Borso, F.; Guercini, S.; Pezzuolo, A.; Zanotto, M.; Sgorlon, S.; Delle Vedove, G.; Miceli, F.; Stefanon, B. The Impact of the Dairy Cow Diet on Anaerobic Digestion of Manure; American Society of Agricultural and Biological Engineers Annual International Meeting: Boston, MA, USA, 2019.

102. Aceves-Lara, C.-A.; Latrille, E.; Conte, T.; Steyer, J.-P. Online estimation of VFA, alkalinity and bicarbonate concentrations by electrical conductivity measurement during anaerobic fermentation. Water Sci. Technol. 2012, 65, 1281-1289. [CrossRef]

103. Pfeiffer, W.; van Nguyen, T.; Neumann, J.; Awe, D.; Tränckner, J. Operation and Control of a Full-Scale Biogas Plant Treating Wastewater from the Cleaning of Car Tanks. Chem. Eng. Technol. 2020, 43, 84-94. [CrossRef]

104. Steyer, J.-P.; Bouvier, J.C.; Conte, T.; Gras, P.; Harmand, J.; Delgenès, J.-P. On-line measurements of COD, TOC, VFA, total and partial alkalinity in anaerobic digestion processes using infra-red spectrometry. Water Sci. Technol. 2002, 45, 133-138. [CrossRef]

105. Ward, A.J.; Bruni, E.; Lykkegaard, M.K.; Feilberg, A.; Adamsen, A.P.S.; Jensen, A.P.; Poulsen, A.K. Real time monitoring of a biogas digester with gas chromatography, near-infrared spectroscopy, and membrane-inlet mass spectrometry. Bioresour. Technol. 2011, 102, 4098-4103. [CrossRef] [PubMed]

106. Stockl, A.; Lichti, F. Near-infrared spectroscopy (NIRS) for a real time monitoring of the biogas process. Bioresour. Technol. 2018, 247, 1249-1252. [CrossRef] [PubMed]

107. Mortreuil, P.; Baggio, S.; Lagnet, C.; Schraauwers, B.; Monlau, F. Fast prediction of organic wastes methane potential by near infrared reflectance spectroscopy: A successful tool for farm-scale biogas plant monitoring. Waste Manag. Res. 2018, 36, 800-809. [CrossRef] [PubMed]

108. IoT (Internet of Things) based efficiency monitoring system for bio-gas plants. In Proceedings of the 2017 2nd International Conference on Computational Systems and Information Technology for Sustainable Solution (CSITSS), Bangalore, India, 21-23 December 2017.

109. Arzate Salgado, J.A. Modeling and Simulation of Biogas Production Based on Anaerobic Digestion of Energy Crops and Manure; Berlin University of Technology: Berlin, Germany, 2019.

110. Ramachandran, A.; Rustum, R.; Adeloye, A.J. Review of Anaerobic Digestion Modeling and Optimization Using Nature-Inspired Techniques. Processes 2019, 7, 953. [CrossRef] 
111. Hill, D.T.; Barth, C.L. A dynamic model for simulation of animal waste digestion. J. Water Pollut. Control Fed. 1977, 49, $2129-2143$.

112. Heyes, R.H.; Hall, R.J. Anaerobic digestion modelling? The role of H2. Biotechnol. Lett. 1981, 3, 431-436. [CrossRef]

113. Hill, D.T. Design parameters and operating characteristics of animal waste anaerobic digestion systems-Swine and poultry. Agric. Wastes 1983, 5, 157-178. [CrossRef]

114. Costello, D.J.; Greenfield, P.F.; Lee, P.L. Dynamic modelling of a single-stage high-rate anaerobic reactor-I. Model derivation. Water Res. 1991, 25, 847-858. [CrossRef]

115. Vavilin, V.A.; Rytov, S.V.; Lokshina, L.Y. A description of hydrolysis kinetics in anaerobic degradation of particulate organic matter. Bioresour. Technol. 1996, 56, 229-237. [CrossRef]

116. Bernard, O.; Hadj-Sadok, Z.; Dochain, D.; Genovesi, A.; Steyer, J.P. Dynamical model development and parameter identification for an anaerobic wastewater treatment process. Biotechnol. Bioeng. 2001, 75, 424-438. [CrossRef]

117. Siegrist, H.; Vogt, D.; Garcia-Heras, J.L.; Gujer, W. Mathematical model for meso- and thermophilic anaerobic sewage sludge digestion. Environ. Sci. Technol. 2002, 36, 1113-1123. [CrossRef] [PubMed]

118. Batstone, D.J.; Keller, J.; Angelidaki, I.; Kalyuzhnyi, S.V.; Pavlostathis, S.G.; Rozzi, A.; Sanders, W.T.M.; Siegrist, H.A.; Vavilin, V.A. The IWA anaerobic digestion model no 1 (ADM1). Water Sci. Technol. 2002, 45, 65-73. [CrossRef] [PubMed]

119. Zaher, U.; Pandey, P.; Chen, S. A simple elemental continuity based model application to study the anaerobic microbial activity for the treatment of dairy manure. Appl. Math. Model 2009, 33, 3553-3564. [CrossRef]

120. Rajendran, K.; Kankanala, H.R.; Lundin, M.; Taherzadeh, M.J. A novel process simulation model (PSM) for anaerobic digestion using Aspen Plus. Bioresour. Technol. 2014, 168, 7-13. [CrossRef] [PubMed]

121. Arzate, J.A.; Ertem, F.C.; Cruz Bournazou, M.N.; Neubauer, P.; Junne, S. Life Cycle Assesment and Modeling Approaches for Biogas Production. In Proceedings of the International Scientific Conference, Novi Sad, Serbia, 19-20 June 2015.

122. Barampouti, E.; Mai, S.; Vlyssides, A. Dynamic modeling of biogas production in an UASB reactor for potato processing wastewater treatment. Chem. Eng. J. 2005, 106, 53-58. [CrossRef]

123. Nopharatana, A.; Pullammanappallil, P.C.; Clarke, W.P. Kinetics and dynamic modelling of batch anaerobic digestion of municipal solid waste in a stirred reactor. Waste Manag. 2007, 27, 595-603. [CrossRef]

124. Yusuf, M.O.L.; Ify, N.L. The effect of waste paper on the kinetics of biogas yield from the co-digestion of cow dung and water hyacinth. Biomass Bioenerg. 2011, 35, 1345-1351. [CrossRef]

125. Syaichurrozi, I.; Sumardiono, S. Biogas production kinetic from vinasse waste in batch mode anaerobic digestion. World Appl. Sci. J. 2013, 26, 1464-1472.

126. Brulé, M.; Oechsner, H.; Jungbluth, T. Exponential model describing methane production kinetics in batch anaerobic digestion: A tool for evaluation of biochemical methane potential assays. Bioproc. Biosyst. Eng. 2014, 37, 1759-1770. [CrossRef]

127. Kara, S.; Mueller, J.J.; Liese, A. Online analysis methods for monitoring of bioprocesses. Chem. Today 2011, 29 , n-2.

128. Lee, C.K.M.; Cao, Y.; Ng, K.H. Big Data Analytics for Predictive Maintenance Strategies. Supply Chain Management in the Big Data Era; IGI Global Business Science Reference; Hershey: Derry Township, PA, USA, 2017; pp. 50-74.

129. Wahmkow, C.; Knape, M.; Konnerth, E. Biogas Intelligence-Operate Biogas Plants Using Neural Network and Fuzzy Logic. In Proceedings of the Computer Science, Joint IFSA World Congress and NAFIPS Annual Meeting, Alberta, Canada, 24-28 June 2013. [CrossRef]

130. Bhuiyan, M.H.; Kundu, P.S. A Model to Produce Combined Clean Energy at Any Scale Maintained by Hi-Tech Artificial Intelligence (AI) and Internet of Things (IOT); International Journal of Scientific \& Engineering Research: Sylhet, Bangladesh, 2019; Volume 10, p. 6.

131. Böhm, R.; Schaidhauf, R.M.; Spanheimer, R.; Erdmann, D.M.; Franke, J. Flexibilization of Biogas Plants through Intelligent Automation Generates Earning Opportunities; Trans Tech Publications Ltd.: Bäch, Switzerland, 2016; pp. 74-80.

132. Wolf, C.; McLoone, S.; Bongards, M. Biogas plant control and optimization using computational intelligence methods. Automatisierungstechnik 2009, 57, 638-649. [CrossRef]

133. Tumer, A.E.; Edebali, S. An artificial neural network model for wastewater treatment plant of Konya. Int. J. Intell. Syst. 2015, 3 , 131-135. [CrossRef]

134. Levstek, T.; Lakota, M. The use of artificial neural networks for compounds prediction in biogas from anaerobic digestion-A review. Agricultura 2010, 7, 15-22.

135. Manu, D.S.; Thalla, A.K. Artificial intelligence models for predicting the performance of biological wastewater treatment plant in the removal of Kjeldahl Nitrogen from wastewater. Appl. Water Sci. 2017, 7, 3783-3791. [CrossRef]

136. Vanti, C.V.M.; Leite, L.C.; Batista, E.A. Monitoring and control of the processes involved in the capture and filtering of biogas using FPGA embedded fuzzy logic. IEEE Latin Am. Trans. 2015, 13, 2232-2238. [CrossRef]

137. Wang, L.; Long, F.; Liao, W.; Liu, H. Prediction of anaerobic digestion performance and identification of critical operational parameters using machine learning algorithms. Bioresour. Technol. 2020, 298, 122495. [CrossRef]

138. De Clercq, D.; Jalota, D.; Shang, R.; Ni, K.; Zhang, Z.; Khan, A.; Wen, Z.; Caicedo, L.; Yuan, K. Machine learning powered software for accurate prediction of biogas production: A case study on industrial-scale Chinese production data. J. Clean. Prod. 2019, 218, 390-399. [CrossRef]

139. Takami, G.; Tokuoka, M.; Goto, H.; Nozaka, Y. Machine Learning Applied to Sensor Data Analysis. Yokogawa Tech. Rep. 2016, $59,27-30$.

140. Huber, W. Industry 4.0 Compact—How Technologies are Changing Our Economy and Our Industry 4.0 Compact-How Technologies Are Changing Our Economy and Our Companies; Springer: Berlin/Heidelberg, Germany, 2018. 
141. Derguech, W.; Burke, E.; Curry, E. An autonomic approach to real-time predictive analytics using open data and internet of things. In Proceedings of the 2014 IEEE 11th Intel Conf on Ubiquitous Intelligence and Computing and 2014 IEEE 11th Intel Conf on Autonomic and Trusted Computing and 2014 IEEE 14th Intel Conf on Scalable Computing and Communications and Its Associated Workshops, Bali, Indonesia, 9-12 December 2014.

142. Jones, M.T. Data Science and Open Source. Learn about Open Source Tools for Converting Data into Useful Information. 2020. Available online: https://www.ibm.com/developerworks/library/os-datascience/os-datascience-pdf.pdf (accessed on 20 September 2020).

143. Industry 4.0 Guideline: Orientation aid for Introduction to Medium-Sized Companies; VDMA Forum Industrie: Frankfurt, Germany, 2015.

144. Fend, L.; Hofmann, J. Digitalisierung in Industrie-, Handels-und Dienstleistungsunternehmen; Springer: Berlin/Heidelberg, Germany, 2018.

145. Reinheimer, S. Industry 4.0; Springer: Berlin/Heidelberg, Germany, 2017.

146. García, M.; Ruiz, J.P.; Basualdo, M. An Approach to Deal with Non-Convex Models in Real-Time Optimization with Modifier Adaptation. In 12th International Symposium on Process Systems Engineering and 25th European Symposium on Computer Aided Process Engineering; Gernaey, K.V., Huusom, J.K., Gani, R., Eds.; Elsevier: Amsterdam, The Netherlans, 2015 ; pp. 899-904. ISBN 9780444634290.

147. Marchetti, A.G.; François, G.; Faulwasser, T.; Bonvin, D. Modifier adaptation for real-time optimization-methods and applications. Processes 2016, 4, 55. [CrossRef]

148. Barchmann, T.; Mauky, E.; Dotzauer, M.; Stur, M.; Weinrich, S.; Jacobi, H.F.; Liebetrau, J.; Nelles, M. Expanding the flexibility of biogas plants-substrate management, schedule synthesis and economic assessment. Landtechnik 2016, 71, $233-251$.

149. Teleszewski, T.J.; Żukowski, M. Analysis of heat loss of a biogas anaerobic digester in weather conditions in Poland. Ecol. Eng. 2018, 19, 242-250. [CrossRef]

150. Theuerl, S.; Herrmann, C.; Heiermann, M.; Grundmann, P.; Landwehr, N.; Kreidenweis, U.; Prochnow, A. The future agricultural biogas plant in Germany: A vision. Energies 2019, 12, 396. [CrossRef]

151. Fachagentur Nachwachsende Rohstoffe e.V. Flexibility of Biogas Plants. Available online: https://fnr.de/fileadmin/allgemein/ pdf/broschueren/Broschuere_Flexibilisierung_Biogas_Web.pdf (accessed on 21 October 2020).

152. Daniel-Gromke, J.; Rensberg, N.; Denysenko, V.; Stinner, W.; Schmalfuß, T.; Scheftelowitz, M.; Nelles, M.; Liebetrau, J. Current developments in production and utilization of biogas and biomethane in Germany. Chem. Ing. Tech. 2018, 90, 17-35. [CrossRef]

153. Simanjuntak, L.E.; Soesilo, T.E.B.; Herdiansyah, H. Analysis of Near Infra Red (NIR) Impact as the Control Process of a Palm Oil Mill and Refinery Plant for Environmental Sustainability. Pol. J. Environ. Stud. 2020, 29, 3013-3021. [CrossRef]

154. Kot, W.; Adamski, M.; Czechlowski, M.; Brylewski, T.; Durczak, K.; Szulc, R. Application of VIS-NIR spectrophotometry to assess organic loading rate of a biogas plant digester. Intercathedra 2016, 32, 82-89.

155. Wiegand, B. Der Weg aus der Digitalisierungsfalle; Springer: Berlin/Heidelberg, Germany, 2018. 